\title{
嘫 $\mathrm{K} \alpha \gamma \mathrm{\gamma}^{1}$
}

Kaygı Uludağ Üniversitesi Fen-Edebiyat Fakültesi Felsefe Dergisi

Uludağ University Faculty of Arts and Sciences Journal of Philosophy

Sayı 26 / Issue 26 | Bahar 2016 / Spring 2016

ISSN: 1303-4251

\section{Research Article}

Araştırma Makalesi

DOI: $10.20981 /$ kuufefd. 94403

\author{
Erhan KUÇLU \\ Research Assistant | Araş. Gör. \\ Uludağ Üniversitesi, Fen-Edebiyat Fakültesi, Sosyoloji Bölümü, Bursa-Türkiye \\ Uludag University, Faculty of Science and Letters, Department of Sociology, Bursa-Turkey \\ erhankuclu@uludag.edu.tr
}

\section{The Absurd Aspect Of The Death Of God}

\begin{abstract}
After the death of God we came up against the loss of supreme value and thus loss of meaning, some philosophers and some writers (especially absurdist ones) call the new world as chaotic and absurd. In this paper, we will investigate the relationship between the death of God and absurdity. Our main question: Does the death of God have the absurdist vein? For this inquiry, first of all, we will try to introduce what is the meaning of the-death-of-God in absurd literature and then we will make a short conceptual analysis of absurd to show relationship between them.
\end{abstract}

\section{Keywords}

Absurd, Absurdity, The-death-of-God, Value, Consume, Meaning, Meaninglessness. 
The existansialist nihilist judges human existence to be pointless and absurd.

In the medieval era, the God was organizing the society and establishing regulations, the God was the supreme value for the men. 'After the death of the God of Abraham, Isaac and Jacob...' (C. Glicksberg 1996: 3) the human beings need another supreme value, because with death of God the man has lost their meaning of life. This meaninglessness is growing and blockading the [social] life, because of this, The Western societies try to find or, in fact build, construct a new meaning sources, the most common and important one is the rationalistic and capitalistic life style. To grasp this transformation and its effects and also the relationship between the death-of-god and meaninglessness of life or the absurd, we viewed the God's death and his role in social life, and then we tried to figure out the connection among the some concepts: The Death of God, Consumer Society and Absurd. In this manner the we can start with Nietzsche's famous declaration about the God:

“...God is dead! God remains dead! And we killed him! How can we console ourselves, the murderers of all murderers! The holiest and mightiest thing the world has ever possessed has bled to death under the our knives: who wipe this blood from us? With what water could clean ourselves? What festivals of atonement, what holy games will we have to invent for ourselves? Is the magnitude of this deed not too great for us? Do we not ourselves have to become gods merely to appear worthy of it? There was never a greater deed - and whoever is born after us will on account of this deed belong to a higher history than all history up to now! (F. Nietzsche 2007: 120)

According to Gianni Vattimo, Nietzsche’s famous phrase: “God is dead” means not that God is inexistent, in the sense of a flat-footed metaphysical pronouncement. It suggests, rather, that the "objective world" can no longer be built on transcendent foundation. God is no longer available to us as the unchanging and immutable first principle who now serves as the basis for morality and truth, as warrant for stable and fixed "metaphysical" positions. In the post-modern age, we must live with endless contingencies rather than with secure and available foundations. And this contingency and provisionality includes the affirmation of a "God" who himself does not escape interpreted existence. Our understanding of God is, and relentlessly so, also an interpretation. (T. Guarino 2009: 6-7) In this context Vattimo claims that "when Nietzsche teaches that God is dead, he doesn't only mean that there are no longer supreme values, he also means that a multitude of values has taken their place at the ruined foundation..." (Mascetti 2002: 452-463) "By this [the death of God] he does nor mean simply that man has lost faith in God; for such a faith could perhaps be regained some day. But the murdered God remains dead. It is not in the power of man to reawaken him to new life; the process is reversible.” (Karsten Harries 1961: 1)

Human beings today need a meaning to maintain their life. But it is problematic aspect of creating a meaning: what kind of value should be, there is a debate on whether it must be it must be personal meaning or it must be universal, and also there is a big ambiguity how can the men create the "universal" meaning without conflict, war or leading to a dictatorship. After death of God the men positioned reason as a supreme 
value or organizer. But after the World Wars the reason has lost its credibility. In the lack of a meaning or universal meaning the men feel himself alienated in the universe, and as a result of this, As Albert Camus said, 'there is but one truly serious philosophical problem, and that is suicide’ (Camus 1955: 5) After the death of God (of Abraham, of Jesus Christ, not of Muhammad) a chaos occurred in the modern Western and in the other countries which try to become westernized. In the modern societies, this chaos make itself apparent in area of values. "Post-death-of-God philosophers are generally agree that there is no meaning of life, that life as such is meaningless; 'chaos' (Nietzsche), 'absurd' (Camus)” (Young 2003: 197). 'Meaninglessness, in its modern sense, can mean any of following, or any combination of thereof: being disconnected or uprooted; being impotent, or not in the control of events; the moral or evaluative leveling of everything; the insignificance or alienation of man in vast, nonhuman universe; the contingency of man; the hollowness or emptiness of life; the failure of the world to answer to man's rationality; the fact that everything adds up to nothing, or very little; the pointlessness of life; the waste of one's life; mechanically going through the motions of life; loss of identity; the-dog-eat-dog quality of life; the power of death to negate everything; the falseness, in-authenticity of one's life; indifference to others; o morally debased quality in things; having lost one's bearings and so on" (G. Blocker 1975: 17-18). From a sociological perspectives, we can argue that there is a essential problem, which this chaos/absurd situation leads, is the suicide, because in the modern world human beings consume everything, put it differently we live in a "consumption society”. As René Girard state:

The consumer society, because it renders objects available, at the same time also makes them eventually undesirable, working towards its own 'consumption'. Like all sacrificial solutions, the consumer society needs to reinvent itself periodically. It needs to dispose of more and more commodities in order to survive. Moreover, the market society is devouring the earth's resources, just as primitive society devoured its victims. However, all sacrificial remedies lose their efficacy because the more available they are, the less effective they become. (...) The consumer society, at its extreme, turns us into mystics in the sense that it shows us that objects will never satisfy our desires. (...) This creates an inflation of objects, the consequence of which is that one now has an array of objects which go directly from the shop to the bin, with hardly a stop in between. One buys objects with one hand, and throws them away with the other - in a world where half of the human population goes hungry (...) It can corrupt us in the sense that it can lead us to all sorts of useless activities, but it also brings us back to an awareness of our need for something entirely different. Something that the consumer society itself cannot provide. (René Girard 2008: 79-81)

For Girard Capitalistic consumer society has to create or product new interesting things which appeal to our desires, for surviving. In the modern capitalist society our main activity is to consume [things which has a meaning for us], in this manner "to consume" is the essential meaning of modern life. For example, capitalism rousingly products new mesmerizer and expensive technological productions at any moment, This expensiveness can be seen a purpose for the poor, but not for all mankind. With the modernization, with the death of God the man lost his cultural, religious roots, and he feels an alienation against "the new world". In his essay: "Nietzsche's Word: God is Dead" German Master Martin Heidegger asks a question which surround the alienation 
period: What is going on with being? (Heidegger 2002: 193) and he sums up the transformation:

The place of God's vanished authority and the Church's profession of teaching has been taken by the authority of conscience and, forcibly, by the authority of reason. The social instinct has risen up against these. Historical progress has replaced the withdrawal from the world into supersensory. The goal of eternal bliss in the hereafter has been transformed into the earthly happiness of the greatest number. The diligent care that was the cultus of religion has been replaced by enthusiasm for creating a culture or for spreading civilization. Creation, once the prerogative of biblical God, has become the mark of human activity, whose creative work becomes in the end business transactions. (Heidegger 2002: 165)

Indeed, After the death of God, Western societies are in need of creation new value which can supersede of God and its organization, but it has become an aporia, to put it another way, it has become a issue which is getting worst day by day, In Nietzschean sense this is "value crisis", and also this crisis is uncanniest of guests: Nihilism. "Nihilism is the breakdown of the order of meaning, where all that we previously imagined as a divine, transcendent basis for moral valuation has become meaningless." (Critchley, 2004: xix) Baudrillard tells us this value crisis which invites the uncanniest of guests: “...Properly speaking there is no law of value, merely sort of epidemic of value, a general metastasis of value , a haphazard proliferation and dispersal of value". (Baudrillard 1993: 5) At this point, he reaches this conclusion, "Indeed we should really no longer speak of 'value' at all, for this kind of propagation or chain reaction makes all valuation impossible” (Baudrillard 1993: 5) This quatation implies that modern world brings forth "the dedifferentiation period" which surround us with a sense of indifference. But according to Existentialist thinkers like Sartre, after the God, we have to make our "meaning/purpose/choices" to live in the world. According to Sartre, God stopped speaking and now it is time to speak for human being; “... (1) God is dead. (2) Since there is no God to authorize the good, we have to do it for ourselves. But (3) we have no authority over ourselves. Hence (4) we possess no authoritative account of the good, and life is meaningless (and so worthless).” (Young 2003:159)

Post-the-death-of-God, without making ultimate choices, human beings cannot get rid of meaningless/absurd life and thus the suicide. As we said above, the suicide is the main problem which absurd situation leads, "The Absurd alienates man from his normal life, it highlights the limits of social ties, it conjures up the spectre of death, it frustrates the mind's desire for clarity." (Dobrez 2014: 179) Camus state that "There is but one truly serious philosophical problem, and that is suicide. Judging whether life is or is not worth living amounts to answering the fundamental question of philosophy" (Albert Camus 1955: 4). In The Myth of Sisyphus, Camus does indeed contemplate why we should not commit suicide. Though a human's situation may be absurd and full of contradictions, suicide is the wrong answer for Camus, because suicide means to give up. Camus tries to understand relationship between absurd and suicide, and he rejects suicide. Before detail his thoughts we should analyze the concept of absurd.

Today there is a vast literature about the concept of absurd and absurdity. The concept of absurd has a complex and wide historical background. İn this essay, at first 
phase, we examined the different descriptions of the absurd, and then we took the different absurd views.

Now we can ask our first question: What is absurd and absurdity? But When we try to give a definition of absurd, we can see that the absurd has a complex historical background and also "absurd is both an experience and a concept" (David Sherman 2009, 21). Mario Pei and Frank Gaynor define "ab-surd" as "unreasonable; contrary to the rules of logic.” (Wegener 1967: 151) In Merriam-Webster Dictionary, explains the absurd as "the state or condition in which human beings exist in an irrational and meaningless universe and in which human life has no ultimate meaning": the absurdity as "the fact of being ridiculous". In The Theatre of Tthe Absurd, Martin Esslin gives a different definition:

“'Absurd' originally means 'out of harmony', in a musical context. Hence its dictionary definition: 'out of harmony with reason or properity; incongruous, unreasonable, illogical' In common usage, 'absurd' may simply mean 'ridiculous', but this is not the sense in which Camus uses the word, and in which it is used when we speak of the Theatre of the Absurd. In an essay on Kafka, Ionesco defined his understanding of the term as follows: 'Absurd is that which is devoid of purpose. ... Cut off from his religious, metaphysical, and transcendental roots, man is lost; all his actions become senseless, absurd, useless.” (Martin Esslin 2001: 18)

In Reassessing The Theatre of the Absurd, Michael Y. Bennett criticizes Esslin's this absurd definition, first of all, he argues that Esslin translates the all-important word, "but," from Ionesco's line, "Est absurde ce qui n'a pas de but ..." as, "Absurd is that which is devoid of purpose . .." The word "but," however, which Esslin translated as "pur-pose," really has more of a sense of "goal” or "target” or "end, ...." (Bennett 2011: 9) And he continues to criticizes his definition: "Stemming from this definition, and its constant and continued use in the field, scholars and common readers alike, most likely because of the influence of this book, have basically understood the absurd and the Theatre of the Absurd as emphasizing the purposeless-ness and senselessness of life." (Bennett 2011: 5) "For Camus and Ionesco", says Bennett, "the absurd was a situation, but not a life sentence of destined meaninglessness or a comment on the world. True, life might not have any inherent meaning, but this stems not from the world, but from the contra-diction between our desires and what the world offers us. However, even given the absurdity of this situation, it is up to us, through our defiance, revolt, and contemplation, to make our lives meaningful.” (Bennet 2011: 10)

In his conception of absurd, Camus mention an irreparable gap which depend on human beings and the world:

What is absurd is the confrontation of this irrational [world] and the wild longing for clarity whose call echoes in human heart. The absurd depends as much on man as on the world. (Camus 1955: 3)

Sartre rejects Camus' understanding of absurd:

Camus' philosophy is a philosophy of the absurd. For him absurd arises from the relation between man and the world, between man's rational demands and the world's irrationality. The themes which he derives from it are those of classical 
pessimism. I do not recognize the absurd in the sense of scandal and disillusionment that Camus attributes to it. What I call the absurd is something very different: it is the universal contingency of being which is, but which is not the basis of its being; the absurd is the given, unjustifiable, primordial quality of existence. (Avi Sagi, 2002: 57)

Despite the Sartre's critique we can assert that Camus' views on absurd has an universal aspects, In Camus absurd view we should accept that we cannot change the world's unreasonable aspects but we can change our perspective. The world can be unreasonable but as a human construction the world can transcend its reality and its absurdity. From this perspective it can be said, Camus’ absurd view, as Gaston Hall expressed, is the rejection of the suicide because the human nature for changeable in Camus' absurd thought. If we change our approach to the world, we can overcome the confrontation. Gene Blocker argues that "absurdity is a property of neither man nor the world alone but of their confrontation.(Blocker, 2013: 27) Blocker In the Myth of Sisyphus we can lots of expression which supports Blocker’s argument:

The mind's deepest desire... is an insistence upon familiarity, an appetite for clarity. Understanding the world for a man is reducing it to the human, stamping it with his seal... The mind that arises to understand reality can consider itself satisfied only by reducing it to terms of thought ... If man realized that the universe like him can love and suffer, he would be reconciled. I said before that the world is absurd, but I was too hasty. This world in itself is not reasonable, that is all that can be said. ... Absurdity consists in the disproportion between intention and reality... The magnitude of the absurdity will be in direct ratio to the two terms of my comparison... Absurdity springs from a comparison... The absurd is essentially a divorce. It lies in neither of the elements compared; it is born of their confrontation... The world is neither so rational nor so irrational. It is unreasonable and only that... It is that divorce between the mind that desires and the world that disappoints... (Camus 1955: 16-37)

In his essay, The Absurd, Thomas Nagel comments Camus' thoughts; "Camus maintains in The MythofSisyphus that the absurd arises because the world fails to meet our demands for meaning.” (Nagel 1971: 721) For Nagel, “absurdity of our stiuation derives not from a collision between our expectations and the world, but from a collision within ourselves. (1971: 722)

In Absurdist Literature "absurdity" is a technical term referring to the devorce of thought from reality, or, as it is variously expressed, the split of word and object, meaning and reality, consciousness and the world. (Blocker 2013: 1) Absurdity, for Ionesco, is the final assault on an already crippled and dottering rationalism, the mainspring of Europe's philosophic, scientific and theological thought for over two thousand years though under increasing attack for the last two hundred. For Ionesco the view that everything, including man, occupies a rational and justifiable niche in a neatly ordered, thoroughly intelligible universe is not only false, but hypocritical and immoral. We must now see through this pretense as a deliberate construction of a false world, a constriction of the real world into a narrow straight-jacket. There is no reason for anything in the world, no final or immediate justification for man's existence, or for any of his actions. The world and human existence, seen from this point of view, is therefore senseless and absurd. (Blocker 1975: 18) 
The central concern of absurdist writers is the metaphysical distancing of word and object, thought and reality, essence and existence. (1975: 2) According to Blocker, "absurdity is the experience of this degeneration of the question of being" (Blocker, 1975: 17) In Heideggerian terms this is the oblivion of the Being. Heidegger reads the history of Western metaphysics as a series of epochs in which philosophers elaborated different interpretations of the being of entities - for example, being as idea in Plato, as energeia in Aristotle, right down to being as eternal recurrence of the same in Nietzsche. Each epoch of metaphysics is characterized by its understanding of the presence of entities and its oblivion of the absence/finitude that makes possible (or "dispenses") that presence. For Heidegger, the last and climactic phase in this "history of being" is our own epoch of technology and nihilism. (Sheehan 2003: 229)

To sum up, Western societies tried to displace or transform their supreme value (God), but they failed. They came up against a value crisis. This transformation period leads to loss of meaning, to a deep pessimism for a meaning seeking and absurd and finally to Nihilism. Today the most predominant and common value for West and thus for the world which traces the West, is capitalism, and Capitalistic world produce new temporary meaning for human being who feels the absurdity of life. Today the world appeals to our desires, and our desires consumes everything! 


\section{Tanrı'nın Ölümünün Absürt Yanı}

\section{Öz}

Bu metin, bir krizin belirtileri hakkında bir soruşturmadır: Değer krizi. Bu manada da Tanrının Ölümüyle ortaya çıkan durumun absürt yönünün bulunup bulunmadığına ilişkin bir incelemedir. Orta çağda toplumu organize eden kurallar Tanrı'nın kurallarıydı, Tanrı fikri sosyal hayatı anlamalı kılan unsurların merkezinde yer almaktaydı. Modernite ile birlikte Tanrı yerinden edilmiştir. Nietzsche'nin meşhur ifadesini kullanırsak "Tanrı öldü". Tanrının ölümünün ardından Batı düşünce dünyasının içine düştüğü durumu filozoflar kaos (Nietzsche) ve absürt (Camus) olarak nitelendirdiler. Metinde ele aldığımız absürt tartışmasının odaklandığı noktada hayatın "anlamsızlığı" meselesidir. Camus absürt'ün ortaya çıktışını en genelde "İnsanın arzuları ile Dünyanın ona sundukları arasındaki uyuşmazlığın yarattığı gerilim olarak" görür. Bu gerilim de, Albert Camus'un felsefenin en temel problemi olarak gördügü "intihar" meselesine işaret eder. Ancak bu absürt durumun çözümü "intihar" değildir zira O’nun için intihar absürtü aşmak değil basitçe vazgeçmektir.

Metinde ilk olarak, Tanrının ölümünün ilanından sonra ortaya çıkan durumun absurtlügünü soruşturmak için Absürt kavramının analizi yapılmıştır. Absürt kavramına ilişkin tanımlar ele ve eleştirilere yer verilmiştir. Bu çerçevede Tanrının ölümü sonrasında anlamlar üreten bir sistem olarak tüketim toplumu’nun ürettiği anlamların geçiciliğine ilişkin başta René Girard olmak üzere eleştirilere yer verilmiştir.

Tüketim toplumuna hizmet eden ve bir noktada toplumun ilgilerini ve algılarını yöneten Kapitalist üretim sosyal hayatın "anlam üreticisi" konumuna erişmiştir. Ancak "geçici" ve cazibesini çabucak yitiren anlamlar neticesinde, Kapitalist üretim tarzı kendisini sonu gelmez bir biçimde yeni anlamlar üretmeye adamıştır. Kapitalist üretim tarzının toplumun ilgsini kendisinde tutmayı başaramadığı kırılma anları toplumun bireylerinin anlamsızlığa savrulduğu anlar olarak ortaya çıkmaktadır.

Tanrısız veya Tanrının kurallarını koymadığı ve organize etmediği bir toplum modelinin önündeki en önemli mesele, Tanrı vari tüketilemez bir anlama ihtiyaç duyulup duyulmadığı meselesidir. Varoluşcu filozoflar örneğin Sartre, Tanrı konuşmadığı bir toplumda anlamın inşasını bireyin iradesine atfetmiştir. Hepimiz bireyler olarak yaşadığımız hayatı anlamlı kılmaya mecburuz.

\section{Anahtar Kelimeler}

Absürt, Tanr'nın Ölümü, Değer, Anlam, Anlamsızlık, Tüketim. 


\section{BIBLIOGRAPHY}

BAUDRILLARD J. (1993) The Transparency of Evil, Verso, New York.

BENNET Michael H. (2011) Reassessing The Theatre of the Absurd, Palgrave Macmillan

BLOCKER, Gene. (1975) The Meaning of Meaninglessness, Martinus Nijhoff.

BLOCKER, Gene. (2013) Metaphysics and Absurdity, University of America.

CAMUS, Albert. (1955) The Mtyh of Sisyphus, Vintage Books

GLICKSBERG, C. (1966) Modern Literature and the death of God, Martinus Nijhoff

CRITCHLEY, Simon. (2004) Very Little...Almost Nothing, Routledge.

DOBREZ, L. A. C. (2014) The Existential and its Exist, Bloomsbury Academic 2014 T\&T Clark

GIRARD Rene. (2008) Evolution and Conversion: Dialoges on the Origin of Culture,

GUARINO T. (2009) Vattimo and Theology, T\&T Clark

HEIDEGGER, Martin. (2002) Off the Beaten Track, Nietzsche's Word: God is Dead, Cambridge University Press

MASCETTI, Yaakov. (2002) Weak Thought and the Reduction of Violence: A Dialog with Vattimo,

NAGEL, Thomas, (1971) The Absurd, http://www.jstor.org/stable/2024942. 716-727

NIETZSCHE, F. (2007) Gay Science, Cambridge University Press.

SAGI Avi. (2002) Albert Camus and The Philosophy of The Absurd. Rodopi.

SHEHAN, Thomas. (2003) "Martin Heidegger", In A Companion to the Philosophers. Second revised edition. Edited by Robert L. Arrington. Blackwell, Oxford

YOUNG, Julian. (2003) The Death of God and the Meaning of Life, Routledg

WEGENER, Adolph. (1967) Absurd In Modern Literature, http://www.jstor.org/stable/40121546 
